\title{
OS ARCOS MAGMÁTICOS PRÉ- A PÓS-COLISIONAIS DA OROGENIA BRASILIANA NA BORDA LESTE DO CRÁTON DE SÃO FRANCISCO
}

\author{
C.Wiedemann
}

$\mathrm{Na}$ região adjacente ao bordo leste do Cráton de São Francisco, correspondente aos Estados de Minas Gerais, Rio de Janeiro e Espírito Santo, o processo de acresção continental compreendeu o desenvolvimento de pelo menos dois Cinturões Móveis: o primeiro de idade Transamazônica e o segundo de idade Brasiliana.

A maior parte do segmento crustal, que atualmente constitui os Estados do Espírito Santo e Rio de Janeiro, foi consolidada durante o Ciclo Brasiliano, do Proterozóico Superior ( 700 Ma) ao Cambro-Ordoviciano (500 a $450 \mathrm{Ma})$. Durante a evolução do Cinturão Móvel Brasiliano, material magmático e sedimentar neo-formado foi metamorfoseado e deformado junto com porções mais antigas de crosta preexistente (Brito Neves \& Cordani, 1991; Söllner et al., 1991).

Dados geofisicos, provenientes de dois perfis gravimétricos da costa ao Cráton (Dias Gomes et al., 1993) apontam para a existência de duas nítidas descontinuidades. A primeira é a descontinuidade de Abre Campo e corresponde ao bordo do Cráton, contíguo ao Cinturão Transamazônico. A segunda é a descontinuidade de Manhuaçu e corresponde ao Cinturão acrescido durante o ciclo Brasiliano/Pan Africano. Os dados geofisicos, disponiveis até o momento, indicam, para o Brasiliano, um único evento acrescional.

Há cerca de 650-600 Ma, durante a fase colisional Brasiliana, anatexia generalizada da crosta preexistente, associada à intrusão de magmas cálcio-alcalinos intermediários a básicos, gerou extensos batólitos granitóides que formam um arco magmático pré- a sin-colisional (Bayer et al., 1986; Wiedemann et al., 1987; Padilha, 1993; Campos Neto \& Figueiredo, 1995). Tais seqüências sofreram metamorfismo de alto grau (fácies anfibolito a granulito) por volta de 600 a $580 \mathrm{Ma}$, tendo ocorrido concomitantemente o desenvolvimento de uma foliação metamórfica $\left(D_{0}\right)$ e dobras fechadas a isoclinais $\left(D_{1}\right)$. 0 redobramento das estruturas $D_{0}$ e $D_{1}$ gerou mega dobras $D_{2}$ com amplitudes maiores que $10 \mathrm{~km}$ e vergência para oeste. Zonas de cisalhamento dúctil foram superpostas ao sistema previamente dobrado, sendo que as mais expressivas e conhecidas são os lineamentos do Guaçuí, Paraíba do Sul e VitóriaMantena. $O$ estilo da deformação caracteriza um típico cinturão transpressivo.

0 batólito pré- a sin-colisional é na verdade a raiz de um arco magmático. Geoquimicamente os ortognaisses são parcialmente relacionados aqueles de um arco vulcânico, com contribuições mantélicas, e foram provavelmente formados numa zona de subducção (Geiger, 1993; Figueiredo \& Campos Neto, 1993). As intrusões batolíticas são de caráter predominantemente metaluminoso, na porção centro sul. $\mathrm{Na}$ região centro norte, devido à contribuição de maiores volumes das fusões de origem metapelítica, começam a predominar os ortognaisses peraluminosos.

As unidades ortoderivadas afloram principalmente na parte central do

Departamento de Geologia - IGEO-CCMN-Universidade Federal do Rio de Janeiro. 
cinturão Brasiliano, sobre a zona de maior espessamento crustal. Com a evolução do processo colisional, várias escamas tectônicas desse pacote ortoderivado foram alojadas por todas as unidades meta-vulcano-sedimentares em menores proporções (Padilha, 1993).

Parte dos magmas cálcio-alcalinos se cristalizou sob condições catazonais secas ou sob condições de altas pressões de $\mathrm{CO}_{2}$ (Sluitner \& Weber-Diefenbach, 1989; Seidensticker \& Wiedemann, 1992) igualmente por volta de $600 \mathrm{Ma}$, formando extensos corpos de charnockitos e granulitos ígneos.

Entre 580 e 560 Ma houve uma segunda fase metamórfica, principalmente na região costeira do Espírito Santo, provocando enderbitização e chamockitização dos gnaisses aluminosos preexistentes. Essa segunda fase metamórfica foi um pouco anterior à intrusão de diápiros tarde a pós-colisionais e, como seria de se esperar, foi acompanhada de um reaquecimento generalizado da crosta. Tal processo teve natureza diversa para regiões diversas, gradando de seco, sob altas pressões de $\mathrm{CO}_{2}$ (enderbitização e charnockitização), principalmente na região costeira, a hidratado (sob altas pressões de $\mathrm{H}_{2} \mathrm{O}$ ), provocando migmatização e nova granitogênese cálcio-alcalina.

No fim do ciclo geotectônico deu-se a formação de um novo arco magmático continental, cujas idades variam de 550 a $450 \mathrm{Ma}$, com a intrusão de vários diápiros inversamente zonados, toleiíticos, cálcio-alcalinos a alcalinos, nas seqüências metamórficas regionais (Wiedemann, 1993). O nível de erosão na região revela, em alguns corpos, as raizes de plútons complexos. Esses apresentam estrutura interna inversamente zonada, formada pela interdigitação de magmas intermediários a básicos no centro e bordas félsicas (granítica a sienomonzonitica) associadas ou não a porções básicas, através de estruturas do tipo "magma mingling". A foliação ígnea é, em geral, bem desenvolvida e paralela à xistosidade dos gnaisses encaixantes.

O Cinturão Móvel Atlântico, aqui focalizado, estende-se para a Faixa Araçuai, em Minas Gerais, Pedrosa Soares et al. (1992), com base nos estudos das seqüências vulcano-sedimentares brasilianas, aflorantes ao longo da margem sudeste do Cráton de São Francisco, reinterpretaram a Faixa Araçuaí como uma paleo margem continental ativa.

No extremo leste dessa Faixa afloram extensos batólitos graníticos que estão em continuidade geográfica e geológica aos arcos magmáticos definidos para o Espírito Santo e Rio de Janeiro. Na região nordeste de Minas Gerais, a granitogênese brasiliana atingiu o seu ápice. Nessa região o espessamento crustal gerou corpos magmáticos cálcio-alcalinos, saturados em sílica, de forma amebóide a circular que chegam a coalescer em impressionantes e complexas estruturas polidiapíricas, atingindo mais de quinhentos quilômetros quadrados de extensão.

\section{Referências Bibliográficas}

BAYER, P.; HORN, H.; LAMMERER, B.; SCHMIDT-THOMÉ, R.; WEBERDIEFENBACH, K.; WIEDEMANN, C. (1986) The brasiliano mobile belt in southern Espirito Santo (Brazil) and its igneous instrusions. Zentralblatt für Geologie und Palaontologie. Teil I, v.9-10, p1429-1439.

BRITO NEVES, B.B.; CORDANI, U.G. (1991) Tectonic evolution of South America during the late proterozoic. Precambrian Research, v.53, n.1-2, p.23-40.

CAMPOS NETO, M.C.; FIGUEIREDO, M.C.H. (1995) The Rio Doce orogeny, southeastern Brazil. Journal South American Earth Scienses, v.8, n.2, p.143-162.

DIAS GOMES, R.A.A.; VASCONCELLOS, R.M.; BARRETO, E.L.; MELETLO, M.J. (1993) Geofisica. In: TULIER, M.P. (org.) Programa levantamentos geológicos básicos do Brasil. Folhas SE 24-Y-C-I-VI; Folhas SE 24-Y-A-I-III. Brasilia, MME/DNPM. (Texto explicativo) 
FIGUEIREDO, M.C.H.; CAMPOS NETO, M. (1993) Geochemistry of the Rio Doce magmatic Arc, southeastern Brazil. Anais da Academia Brasileira de Ciências. Suplemento, v.65, n.1, p.63-81.

GEIGER, A. (1993) Munchner Geographische Hefte, v.11, 217p.

PADILHA, A.V. (1993) Evolução geológica. In: TULIER, M.P. (org.) Programa levantamentos geológicos básicos do Brasil. Folhas SE 24-Y-C-I-VI; Folhas SE 24-Y-AI-III. Brasília, MME/DNPM. (Texto explicativo)

PEDROSA SOARES, A.C.; NOCE, C.M.; VIDAL, P.; MONTEIRO, R.L.B.P.; LEONARDOS, O.H. (1992) Toward a new tectonic model for the late proterozoic Araçai (SE Brazil-West Congolian (SW Africa) belt. Journal South American Earth Sciences, v.6, n.1-2, p.33-47.

SEIDENSTICKER, U.; WIEDEMANN, C. (1992) Geochemistry and origin of lower crustal granulite facies rocks in the Serra do Caparaó region, Espirito Santo/Minas Gerais, Brazil. Journal of South American Earth Sciences, v.6, n.4, p.289-298.

SLUITNER, Z.; WEBER-DIEFENBACH, K. (1989) Geochemistry of charnoenderbitic granulites and associated amphibolitic gneisses in the coastal region of Espirito Santo, Brazil. Zentralblatt für Geologie und Palaontologie. Teil I, v.5-6, p.917-931.

SÖLLNER, F.; LAMMERER, B.; WEBER-DIEFENBACH, K. (1991) Munchner Geographische Hefte, v.4, 100p.

WIEDEMANN, C.; PENHA, H.M.; SCHMIDT-THOMÉ, R. (1987) Granitoids of Espirito Santo and Rio de Janeiro states. Revista Brasileira de Geociências, v.17, n.4, p.674-689.

WIEDEMANN, C. (1993) The evolution of the early paleozoic late to post collisional magmatic arc of the coastal mobile belt, in the state of Espirito Santo, eastern Brazil. Anais da Academia Brasileira de Ciencias. Suplemento, v.65, n.1, p.163-181. 